\title{
Business Freedoms and Employment Rights in the European Union
}

\author{
feremias Prassl*
}

\begin{abstract}
In this article, I explore the substance and operation of Article 16 of the European Union's Charter of Fundamental Rights, which recognises 'the freedom to conduct a business', in order to determine the extent to which the constitutionalisation of commercial interests as fundamental rights could pose a threat to the Union's worker-protective acquis. Having surveyed three important Directives which regulate employees' rights in transfers of undertakings, collective redundancies, and the organisation of working time, I argue that future challenges based on Article 16 CFR are unlikely to succeed: even in situations where the Directives limit employers' economic freedoms, such interference is justified and proportionate.
\end{abstract}

Keywords: EU Employment Law; Article 16 CFR; Freedom to Conduct a Business; Freedom of Contract; Acquired Rights Directive; Collective Redundancies Directive; Working Time Directive.

\section{Introduction}

The impact of the Charter of Fundamental Rights (CFR) on EU labour or employment law has long been the subject of extensive academic debate. ${ }^{1}$ The late

\footnotetext{
* Associate Professor in the Faculty of Law and Fellow of Magdalen College; Research Fellow, Institute for European and Comparative Law, University of Oxford. I am grateful to Catherine Barnard, Mark Freedland, Amy Ludlow, Jonathan Morgan and an anonymous reviewer, as well as the participants at a CELS lunchtime seminar in February 2015 for earlier discussion. The usual disclaimers apply. For questions and comments, please email jeremias.prassl@law.ox.ac.uk.

${ }^{1}$ Including D Ashiagbor, 'Economic and social rights in the European charter of fundamental rights.' (2004) 9 EHRLR 62; T Hervey and J Kenner (eds), Economic and Social Rights under the EU Charter of Fundamental Rights: A Legal Perspective (Oxford, Hart Publishing, 2003)
} 
Brian Bercusson concluded that 'on balance ... the EU Charter is a positive contribution to labour law in the EU'. ${ }^{2}$ At the same time, however, he acknowledged that certain provisions in the Charter might be used to 'further a very different agenda'. ${ }^{3}$ Following the Court of Justice's decision in Alemo-Herron, ${ }^{4}$ there are growing concerns that this could be true, in particular, for a provision contained in the Charter's Chapter II: the Freedom to conduct a business, which is 'recognised' by Article 16 CFR 'in accordance with Union law and national laws and practices'. ${ }^{5}$

In comparison with many other aspects of the Charter, Article 16 CFR is a novel construct. ${ }^{6}$ Previous analyses of the Freedom to Conduct a Business have furthermore rarely strayed into its implication for that part of the Union acquis which is dedicated to regulating the relationship between employers and workers. When the United Kingdom's implementation of the Acquired Rights Directive ${ }^{7}$ was successfully challenged as a violation of an employer's freedom to conduct their business in AlemoHerron, ${ }^{8}$ the Court's decision thus came as a surprise to EU and employment lawyers alike. It was soon condemned by a range of authors for its departure from established lines of reasoning both within EU labour law and as regards the application of the Charter of Fundamental Rights. ${ }^{9}$ Steve Weatherill in particular suggested that the Court's approach was 'so downright odd that it deserves to be locked into a secure container, plunged into the icy waters of a deep lake and forgotten about.' 10

\footnotetext{
2 B Bercusson, European Labour Law (2nd Edn Cambridge 2009) 214.

${ }^{3}$ Bercusson, European Labour Law (n 2) 215.

${ }^{4}$ Alemo-Herron And Others v Parkwood Leisure Ltd, C-426/11, EU:C:2013:521.

${ }^{5}$ Charter of Fundamental Rights of the European Union [2000] OJ C364/01 ('CFR'), Art 16.

${ }^{6}$ For an important early analysis, see M Everson and R Correia Gonçalves, 'Article 16' in S Peers, T Hervey, J Kenner and A Ward (eds) The EU Charter of Fundamental Rights: A Commentary (Beck, Hart, Nomos 2014.

${ }^{7}$ Council Directive (EC) 23/2001 on the approximation of the laws of the Member States relating to the safeguarding of employees' rights in the event of transfers of undertakings, businesses or parts of undertakings or businesses [2001] OJ L82/16 ('Acquired Rights Directive' or 'ARD').

${ }^{8}$ Alemo-Herron And Others v Parkwood Leisure Ltd, EU:C:2013:521.

${ }^{9} \mathrm{~S}$ Weatherill, Use and Abuse of the EU's Charter of Fundamental Rights: on the improper veneration of 'freedom of contract' (2014) 10 ERCL 157, 157; J Prassl, 'Freedom of Contract as a General Principle of EU Law? Transfers of Undertakings and the Protection of Employer Rights in EU Labour Law (Case C-426/11 Alemo-Herron v Parkwood Leisure)' (2013) 42 ILJ 434.

${ }^{10}$ Weatherill, 'Use and Abuse of the EU's Charter of Fundamental Rights' (n 9) 157.
} 
Even if Alemo-Herron can therefore be characterised as an aberration which the Court has refused to follow in subsequent decisions, ${ }^{11}$ the judgment nonetheless raises a series of deeper problems: Could the Union's fundamental rights apparatus come to challenge the application and interpretation of EU labour law, ${ }^{12}$ whether at the Union level or domestically? If so, how might such challenges be framed? And would they be likely to succeed? ${ }^{13}$

In the labour law literature, discussion of the Charter to date has focussed primarily on Chapters such as III (Equality) and IV (Solidarity): ${ }^{14}$ areas in which its provisions have the potential to strengthen workers' rights in national law and at the Union level. ${ }^{15}$ This is not to suggest, of course, that fundamental rights have always been seen as an unconditional blessing: the Court's decision in Viking Lines is deeply problematic precisely because it recognised the defendant trade union's right to strike as forming part of EU law, only then to subordinate it to the employers' internal market freedoms. ${ }^{16}$

The recognition of business freedoms in Article 16 of the Charter, on the other hand, might be significantly more problematic for employment rights than the usual suspects - from the fundamental freedoms to competition law - which lie at the heart of the European Union's economic constitution. First, because it has the potential to turn the received role of fundamental rights as a counterbalance to other elements of Union law, such as the provisions on Free Movement, on its head. ${ }^{17}$ The Charter elevates a dangerously open-ended notion of business freedom to the normative level

\footnotetext{
${ }^{11}$ See eg Österreichischer Gewerkschaftsbund, C-328/13, EU:C:2014:2197.

12 B Bercusson, S Clauwaert and I Schomann 'Legal prospects and legal effects of the EU Charter' in B Bercusson (ed) European Labour Law and the EU Charter of Fundamental Rights (Nomos 2006) 49.

${ }^{13}$ These questions are made more pressing by the fact that at least one such reference has only very recently been lodged before the Court: AGET Iraklis, C-201/15 (pending).

${ }^{14}$ See for example B Bercusson (ed), European Labour Law and the EU Charter of Fundamental Rights (Nomos 2006).

15 Though this potential is not necessarily always realised: C-176/12, Association de Mediation Sociale (AMS), EU:C:2014:2.

${ }^{16}$ A C L Davies, 'One step forward, two steps back? The Viking and Laval cases in the ECJ' (2008) 37 ILJ 126.

${ }^{17}$ Art $26 \mathrm{ff}$ of the Consolidated Version of the Treaty on the Functioning of the European Union [2008] OJ C1 15/49 ('TFEU'); International Transport Workers' Federation and Finnish Seamen's Unionv Viking Line APB, C-438/05, EU:C:2007:772 and Laval un Partneri Ltd v Svenska Byggnadsarbetareförbundet, G341 /05, EU:C:2007:809; M Freedland and J Prassl (eds), EU Law in the Member States: Viking, Laval and Beyond (Hart 2014).
} 
of fundamental rights. As nearly all of employment law can be seen as an interference with employers' freedoms, Article 16 CFR will easily be engaged, with the conceptual apparatus of fundamental rights protection thus providing the basis for challenges to employment legislation

A second problem lies in the fact that Article 16 of the Charter will not be subject to the well-rehearsed limitations inherent in, or judicially developed for, most other 'economic' aspects of EU law:18 from competition law immunity ${ }^{19}$ to internal market law's in-built sensitivity to competing regulatory concerns. ${ }^{20}$ Finally, whilst the reach of free movement law is clearly limited to cross-border scenarios, the fundamental rights guaranteed by the Charter know of no such bounds. ${ }^{21}$

Against this background, the present article hopes to analyse the scope and content of Article 16 GFR with a view to exploring the extent to which, if at all, it might be used as the basis for future challenges to EU employment law measures. A first section explores the development of Article 16 GFR from a broad constitutional principle to its more recent incarnation as a subjective right, before setting out the potential substantive content of the vague and open-ended freedom to conduct a business, and illustrating the Court's approach to Article 16 CFR-based challenges in other areas of EU law. A second section then turns to the application of those tests to three different EU labour law measures which regulate workers' rights during transfers of undertakings, in collective redundancies, and in relation to working time and annual leave. As each of these examples demonstrates, despite the Court's decision in Alemo-Herron, it is highly unlikely that future challenges to the labour law acquis on the basis of Article 16 CFR would succeed. A brief conclusion, finally, turns to the broader constitutional implications of the Charter's recognition of business freedoms as a fundamental right.

\footnotetext{
18 Though it does of course have other limits, as explored in the subsequent sections. ${ }^{19}$ Albany International BV v Stichting Bedrïfspensioenfonds Textielindustrie, C-67/96, EU:C:1999:430. For a powerful defence of this approach, see A Bogg, 'Viking and Laval: The International Labour Perspective', in M Freedland and J Prassl (eds), EU Law in the Member States: Viking, Laval and Beyond (Hart 2014) 71-72.

${ }^{20}$ S Weatherill, 'Viking and Laval: The EU Internal Market Perspective' in M Freedland and J Prassl (eds), EU Law in the Member States: Viking, Laval and Beyond (Hart 2014) 23.

${ }^{21}$ cf Article 51 CFR, and the Court's decision in Fransson, G-617/10, EU:C:2013:280.
} 


\section{Article 16 CFR: from Constitutional Principle to Subjective Right}

In the context of a human rights document marked by a clear commitment not to create novel rights, ${ }^{22}$ the inclusion of Article 16 CFR represents a stark example of legal innovation, making the Charter the 'first legally binding document to explicitly recognize the freedom to conduct a business in the EU legal order'. ${ }^{23}$ This openended formulation, Everson and Gonçalves suggest, is the result of the right's 'dual character', ${ }^{24}$ with Article 16 CFR expressing a commitment to business freedom at both a general, constitutional, and a subjective, individual, level. As regards the first, constitutional dimension, 'the core essence of the freedom to conduct business is one of a general principle of economic autonomy that unfolds within the prescribed contours of the legal-economic institutions of the European Economic Constitution. ${ }^{25}$ Viewed thus, Article 16 CFR provides a counterweight to the growing 'scope and breadth of ... social concerns as justification for trade-restrictive practices and more generally as matters of constitutional relevance in the making and the interpretation of EU law'26 which some commentators had expected following the affirmation of the Charter's status at 'the same legal value as the Treaties. ${ }^{27}$

It is however unlikely that this shift in emphasis at the general, constitutional, plain, could be understood as a challenge to the labour law acquis. First, because Article 16 GFR does not commit the Union to recognise business freedom in the face of employment rights. Second, because even the constitutional protection of economic

\footnotetext{
${ }^{22}$ See in particular the evidence of Lord Goldsmith, the UK representative to the convention tasked with drafting the Charter: HC European Scrutiny Committee, The Application of the EU Charter of Fundamental Rights in the UK: a State of Confusion (43 ${ }^{\text {rd }}$ report, HC 979 2013-14) 13ff, and materials cited there.

${ }^{23}$ A Usai, 'The Freedom to Conduct a Business in the EU, Its Limitations and Its Role in the European Legal Order' (2013) 14 German Law Journal 1867, 1868; see also D Spielman, Liberté d'entreprise (Commentary of the Charter of Fundamental Rights), available at http://ec.europa.eu/justice/fundamental-rights/files/networkcommentaryfinal_en.pdf (last accessed 1 May 2015). Union law had of course long recognised such freedoms implicitly: see the discussion of Nold KG v Commission, C-4/73, EU:C:1974:51, below.

${ }^{24}$ Everson and Correia Gonçalves, 'Article 16' (n 6) 447.

${ }^{25}$ Everson and Correia Gonçalves, 'Article 16' (n 6) 441.

${ }^{26}$ Weatherill, 'Use and Abuse of the EU's Charter of Fundamental Rights' (n 9) 166; idem, 'From Economic Rights to Fundamental Rights' in S de Vries et al (eds) The Protection of Fundamental Rights in the EU After Lisbon (Hart 2013) 13.

${ }^{27}$ Art 6(1) TEU.
} 
rights in a number of Member States has always seen such freedoms as operating in tandem with social rights. ${ }^{28}$ Any notion of 'economic autonomy' at the constitutional level, finally, is sustained, rather than undermined, by labour law. ${ }^{29}$ As Alain Supiot has noted, it is only the advent of social law which 'made the exploitation of labour as a commodity both economically and politically durable'30 in the context of a social market economy.

Mario Monti's report on the future of the internal market 'at the service of Europe's economy and society' similarly recognised the importance of labour law and social law to ensure the stable operation of the internal market, and thus the constitutional foundations of the European Union. Monti explicitly warns of a

'divide between advocates of greater market integration and those who feel that the call for economic freedoms and for breaking up regulatory barriers is code for dismantling social rights protected at national level [... with] the potential to alienate from the Single Market and the EU a segment of public opinion, workers' movements and trade unions, which has been over time a key supporter of economic integration.'31

At the first, constitutional, level it is thus highly unlikely that the freedom to conduct a business could form the basis for challenging the role of employment law within the Union's legal order. This is the consequence both of the importance of labour market regulation to the very operation of an internal market where business freedoms can be exercised, and also because of several explicit commitments to employment rights in the Treaties as well as the Charter itself. The 'dual character' of the freedom could

\footnotetext{
${ }^{28}$ E.g. the Italian Constitution of December 1947 (as amended), Article 41: 'Private-sector economic initiative is freely exercised. It cannot be conducted in conflict with social usefulness or in such a manner that could damage safety, liberty and human dignity. The law shall provide for appropriate programmes and controls so that public and private-sector economic activity may be oriented and coordinated for social purposes.'

29 Though note the important question as the interaction between Union law and Member State law, which is beyond the scope of the present discussion: D Ashiagbor, 'Unravelling the Embedded Liberal Bargain: Labour and Social Welfare Law in the Context of EU Market Integration' (2013) 19 ELJ 303. ${ }^{30}$ A Supiot, 'Grandeur and Misery of the Social State (2013) 82 NLR 99, 104. See also S Deakin, 'Conceptions of the Market in Labour Law', in Q Numhauser-Henning and M Rönnmar, eds, Normative Patterns and Legal Developments in the Social Dimension of the EU (Hart 2013) 141, 150

${ }^{31}$ M Monti, A New Strategy For The Single Market At The Service Of Europe's Economy And Society: Report to the President of the European Commission (9 May 2010) 68.
} 
furthermore make it a much weaker review standard: given Article 16 CFR's wording as a limited freedom, the authors of the Charter may well have hoped to emphasise its constitutional dimension.

\section{A The Open-Ended Content of Article 16 GFR}

This conclusion, however, should not be taken as a suggestion that EU labour lawyers could safely ignore the subjective dimension of Article 16CFR. Its role as an individual right freely to conduct one's business raises two important issues: What is the substance of the freedom? And how would it operate in challenging Union action or legislation? As regards the former question, establishing the precise (and thus judicially enforceable) content of the Charter's open-ended language might appear to be a somewhat elusive task - not least because of a scarcity of 'explicit national constitutional references to notions concomitant'. ${ }^{32}$ Even the Charter's explanatory notes are surprisingly succint: ${ }^{33}$

[Article 16] is based on Court of Justice case-law which has recognised freedom to exercise an economic or commercial activity (see judgments of 14 May 1974, Case 4/73 Nold [1974] ECR 491, paragraph 14 of the grounds, and of 27 September 1979, Case 230-78 SpA Eridiana and others [1979] ECR 2749, paragraphs 20 and 31 of the grounds) and freedom of contract (see inter alia Sukkerfabriken Nykøbing judgment, Case 151/78 [1979] ECR 1, paragraph

19 of the grounds, and judgment of 5 October 1999, C-240/97 Spain v Commission [1999] ECR I-657 1, paragraph 99 of the grounds) ...

In the light of this guidance, it is possible to address two related questions surrounding the substantive content of Article 16 CFR. Is it, first, a general freedom to exercise economic or commercial activity, free from regulatory interference? Secondly, might the freedom enshrined in Article 16 CFR be something more specific, such as the notion of freedom of contract mentioned explicitly in the guidance notes? As Dorota Leczykiewicz has argued, Art 16 CFR could be seen as 'promoting private autonomy

\footnotetext{
32 Everson and Correia Gonçalves, 'Article 16' (n 6) 445.

${ }^{33}$ Explanations Relating to the Charter of Fundamental Rights [2007] OJ C303/17.
} 
in a liberal sense, understood as freedom from regulation and coercion.' More specifically, she suggests, it could provide a new way for private parties to have 'a more concrete and entrenched mechanism of resisting regulatory effects of national and EU law.' ${ }^{34}$ As a brief survey of relevant materials in the subsequent paragraphs will suggest, however, this position is, with respect, not tenable in the light of the current state of Union law as set out in the Treaties, secondary legislation, and the jurisprudence of the Court of Justice.

A notion of business or commercial freedom has of course long been recognised in EU law, dating back to the Court's decision in Nold in the autumn of 1979: the very 'construction of freedom to conduct a business as a primary human right coincides with the birth of human rights law within the European legal order as a whole'. ${ }^{35}$ At the same time, however, it is important to remember the precise context in which these economic freedoms were recognised; and perhaps even more importantly, to recall the conditions with which they were immediately qualified.

In Nold, the eponymous coal dealers had challenged a Commission decision which had directly threatened their ability to carry on a small wholesale business by stipulating certain minimum purchase quantities. The company's final ground of challenge was that the Commission's action would have had the effect 'of jeopardizing both the profitability of the undertaking and the free development of its business activity, to the point of endangering its very existence'36 - and would thus violate the undertaking's fundamental rights. In one of the most frequently cited paragraphs of Union law, the Court in reply recognised that 'fundamental rights form an integral part of the general principles of law', ${ }^{37}$ before going on to set out a crucial series of limitations:

... the rights thereby guaranteed, far from constituting unfettered prerogatives, must be viewed in the light of the social function of

\footnotetext{
${ }^{34}$ D Leczykiewicz, 'Horizontal Effect of Fundamental Rights: In Search of Social Justice or Private Autonomy in EU Law?' in U Bernitz, X Groussot \& F Schulyok (eds), General Principles of EU Law and European Private Law (Kluwer Law International 2013) 172.

35 Everson and Correia Gonçalves, 'Article 16' (n 6) 440

${ }^{36}$ Nold KG v Commission, EU:C:1974:51, paragraph 12.

37 Nold KG v Commission, EU:C:1974:51, paragraph 13.
} 
the property and activities protected thereunder. For this reason, rights of this nature are protected by law subject always to limitations laid down in accordance with the public interest ... [and] justified by the overall objectives pursued by the community, on condition that the substance of these rights is left untouched.

As regards the guarantees accorded to a particular undertaking, they can in no respect be extended to protect mere commercial interests or opportunities, the uncertainties of which are part of the very essence of economic activity. ${ }^{38}$

On the facts of the case, the Court held that the trader's right had not been violated, thus laying the foundation for an approach which it has followed with surprising consistency ever since: whilst a commitment to free economic activity is recognised, the exercise of such rights must always be reconciled with other objectives - whether they are competing fundamental rights, or Union law more generally. ${ }^{39}$ Indeed, this balanced approach is reflected in the very core of the European Union's economic impetus, the fundamental freedoms of movement: there is no 'individual right to trade capable of vindication via $\mathrm{EC}$ internal market law', ${ }^{40}$

The second limb of Article 16 CFR set out in the guidance notes is the notion of freedom of contract. Similar reservations apply mutatis mutandis. As regards the content of that principle, first, it is very difficult to see how this could be imbued with a consistent meaning as an autonomous concept in Union law - not least given the many divergent meanings hiding behind a beguilingly simple term. ${ }^{41}$ Even a brief survey of the case law cited in the guidance notes, second, illustrates that the principle was always recognised subject to abrogation by legislation or other rules. In Spain v Commission, for example, the Court acknowledged the existence of a 'principle of contractual freedom', but was willing to uphold it only insofar as it could not 'be

\footnotetext{
${ }^{38}$ Nold KG v Commission, EU:C:1974:51, paragraph 14.

39 SpA Eridiana and others, C-230-78, EU:C:1979:216, paragraph 31.

${ }^{40}$ S Weatherill, 'After Keck: Some Thoughts on How to Clarify the Clarification’ (1996) 33 GMLR 885, 904.

${ }^{41}$ Prassl, 'Freedom of Contract as a General Principle of EU Law?' (n 9); building on S Whittaker, 'The Optional Insutrument of European Contract Law and Freedom of Contract (2011) 7 ERCL 371, 372.
} 
limited in the absence of Community rules imposing specific restrictions in that regard.' ${ }^{42}$

\section{B Article 16 GFR as a Subjective Right in Operation}

Given its open-ended content, including both some form of economic or business freedom, as well as the notion of freedom of contract, it is unsurprising that Article 16 CFR is worded as a heavily qualified freedom, rather than as an absolute right. As Everson and Gonçalves suggest, this 'unique formulation ... raises an assumption that its exercise is limited, by contrast to rights to work and property. ${ }^{43}$ It is to the operation of these potential limitations that discussion now turns.

The final sentences of the explanatory notes stipulate that ' $[\mathrm{o}] \mathrm{f}$ course, [Article $16]$ is to be exercised with respect for Union law and national legislation. It may be subject to the limitations provided for in Article 52(1) of the Charter.' 44 This annotation reflects important last-minute qualifications agreed in a draft prepared for the European Council in advance of its meeting in Biarritz on 13-14 October 2000, where the text of Article 16 CFR 'was amended from "the freedom to conduct a business is recognised" to "the freedom to conduct a business in accordance with Community law and national laws and practices is recognised".'45

Given these multi-pronged qualifications, drawing on provisions of the Union legal order as well as the 'laws and practices' of the 28 Member States, the formulation of Article 16 CFR therefore suggests that it should rarely win the day when used as the basis for an individual's challenge against Union measures. ${ }^{46}$ Indeed, with the exception of Alemo-Herron, discussed in the next section, Article 16 CFR has

\footnotetext{
42 Spain v Commission, C-240/97, EU:C:1999:479, paragraph 99.

${ }^{43}$ Everson and Correia Gonçalves, 'Article 16' (n 6) 444.

${ }^{44}$ Explanations Relating to the Charter of Fundamental Rights (n 33).

${ }^{45}$ http://www.eurofound.europa.eu/eiro/2000/10/inbrief/eu0010273n.htm (last accessed 1 May 2015).

46 The same is true for (increasingly frequent) situations where Article 16CFR is used as a subsidiary or alternative ground of challenge.
} 
only rarely won the day, ${ }^{47}$ despite its increasingly frequent use in a range of cases: private actors have relied on their freedom to conduct a business to challenge Union measures ranging from provisions for the tagging of animals ${ }^{48}$ and assistance and compensation for air passengers whose flights have been delayed or cancelled ${ }^{49}$ to international sanctions. ${ }^{50}$

The resulting body of case law on the application of Article 16 of the Charter reveals an emerging pattern as to how the Court evaluates and applies the Freedom to Conduct a Business. An important early case was Deutsches Weintor, ${ }^{51}$ where traders challenged the German interpretation of the Health Claims Regulation, ${ }^{52}$ which had lead domestic authorities to restrict claims that particular wines were 'bekömmlich', or easily digestible. In turning to the Charter, the Court recognised that whilst the referring Court had focussed its questions on Articles 15 and 16 CFR, all competing interests protected in the Charter were to be taken into account, including on the facts of Deutsches Weintor the protection of health (Article 35 CFR). ${ }^{53}$ The subsequent assessment of these competing interests was then to be 'carried out in accordance with the need to reconcile the requirements of the protection of those various fundamental rights..., striking a fair balance between them. ${ }^{54}$

This approach was endorsed by the Grand Chamber in its decision in Sky Österreich. ${ }^{55}$ There, the Court held that whilst certain aspects of the Broadcasting Directive ${ }^{56}$ under scrutiny may well

\footnotetext{
${ }^{47}$ With the notably exception of Scarlet Extended SA v Société belge des auteurs, compositeurs et éditeurs SCRL (SABAM), C-70/10, EU:C:2011:771. This decision, however, can be understood in the highly specialised context of Intellectual Property law and the proposed application of very onerous blanket obligations to Internet Service Providers.

${ }^{48}$ Herbert Schaible Co, C-101/12, EU:C:2013:661.

${ }^{49}$ Denise McDonagh v Ryanair Ltd, G-12/11, EU:C:2013:43.

${ }^{50}$ Council v Kala Naft Co, C-348/12P, EU:C:2013:776.

${ }^{51}$ Deutsches Weintor, C-544/10, EU:C:2012:526.

${ }^{52}$ Regulation (EG) No 1924/2006 of the European Parliament and of the Council of 20 December 2006 on nutrition and health claims made on foods (OJ 2006 L 404, p. 9), as last amended by Commission Regulation (EU) No 116/2010 of 9 February 2010 (OJ 2010 L 37, p. 16; 'Regulation No 1924/2006').

${ }^{53}$ Deutsches Weintor, EU:C:2012:526, paragraph 46.

${ }^{54}$ Deutsches Weintor, EU:C:2012:526, paragraph 47.

55 Sky Österreich GmbH v Österreichischer Rundfunk, C-283/11, EU:C:2013:28.

${ }^{56}$ Directive 2010/13/EU of the European Parliament and of the Council of 10 March 2010 on the coordination of certain provisions laid down by law, regulation or administrative action in Member
} 
amount to inference with the freedom to conduct a business of holders of exclusive broadcasting rights, ... in accordance with the Court's case-law, the freedom to conduct a business is not absolute, but must be viewed in relation to its social function. [Article 16CFR may therefore] be subject to a broad range of interventions on the part of public authorities which may limit the exercise of economic activity in the public interest. ${ }^{57}$

On the basis of this broad power to limit the scope of Article 16 GFR, even the potentially onerous obligation to provide certain material covering 'events of high interest to the public'58 to competing broadcasters at negligible cost was held not to 'affect the core content of the freedom to conduct a business', as it did 'not prevent a business activity from being carried out as such by the holder of exclusive broadcasting rights. 59

In practice, this 'core content' test is likely to constitute the most important hurdle to the success of any action brought to vindicate an individual's economic freedoms under Article 16 CFR, especially once it is applied in combination with the Court's proportionality scrutiny against a right's social function. ${ }^{60}$ In the words of Article 52(1) CFR, any limitations on rights and freedoms set out in the Charter must be 'necessary and genuinely meet objectives of general interest recognised by the Union or the need to protect the rights and freedoms of others.' Chapter IV, for example, provides a host of provisions on which such resistance could be based - from workers' information and consultation rights (Article $27 \mathrm{CFR}$ ) and a right to collective bargaining and action (Article 28 CFR) to protection in the event of unjustified dismissal (Article $30 \mathrm{CFR}$ ) and a broadly-framed right to fair and just working conditions (Article 31 CFR). Their content is strengthened further by the emergence of a 'general principle of the protection of the weaker party in civil law relations', such

States concerning the provision of audiovisual media services (OJ 2010 L 95, p. 1, and corrigendum OJ 2010 L 263, p. 15).

57 Sky Österreich GmbH v Österreichischer Rundfunk, EU:C:2013:28, paragraphs 45-46; citing Deutsches Weintor, EU:G:2012:526, paragraph 54.

58 Audiovisual Media Services Directive (n 50), Art 15(6).

${ }^{59}$ Sky Österreich GmbH v Österreichischer Rundfunk, EU:C:2013:28, paragraph [49].

${ }^{60}$ Wachaufv Germany, C-5/88, EU:C:1989:321, paragraph [18]. 
as the contract of employment, as charted by Norbert Reich. ${ }^{61}$ The importance of these objectives, finally, 'may justify restrictions which bring about even substantial negative consequences for certain economic operators' ${ }^{62}$

\section{Article 16 GFR as a Challenge to EU Labour Law?}

Having thus set out the basic contours of the content and operation of Article 16, discussion turns to a series of specific employment law Directives in order to determine the extent to which, if at all, their provisions might be said to infringe the freedom to conduct a business now enshrined in the Charter - and, if so, how any such interference could be justified. To this end, sub-section A returns to the muchdiscussed decision in Alemo-Herron, where the Court applied Article 16 CFR in interpreting the Acquired Rights Directive; with subsequent sub-sections focussed on Directives regulating Collective Redundancies and Working Time.

\section{A The Acquired Rights Directive}

In Alemo-Herron, the Court was asked whether 'dynamic' clauses incorporating future collective agreements into individual contracts of employment were capable of binding the transferee of a business by falling within the scope of Article 3(3) of the Acquired Rights Directive (ARD). At first glance, the answer to that question would appear to be rather straightforward from the text of Directive. Once its regulatory regime applies, contracts of employment will not terminate upon a transfer of the business or part thereof. Instead, the transferor's rights and obligations will be transferred to the transferee. ${ }^{63}$ Article $3(3)$ of the ARD specifically extends this protection to collective agreements, subject only to the termination, expiry or renewal of existing agreements, and an optional limitation period of 12 months.

\footnotetext{
${ }^{61}$ N Reich, General Principles of EU Civil Law (Intersentia 2014) 40, and chapter 2 more generally. ${ }^{62}$ Nycomed Danmark ApS v European Medicines Agency (EMA), T-52/09, EU:T:201 1:738, paragraph 89.

${ }^{63}$ Acquired Rights Directive (n 7) Art 3(1).
} 
Following the transfer of Mr Alemo-Herron's employment in a public sector leisure department to the private sector, his new employer had refused to increase pay in line with public sector collective bargaining, thus raising the question whether Article 3 of the Directive precluded Member States from stipulating that dynamic incorporation clauses were enforceable against the transferee. ${ }^{64}$ In answering that question in the affirmative, the judgment relied on two strands of reasoning: first, that the ARD's regime required a balance between employee and employer interests, and second, that due weight was to be given to the principle of freedom of contract as a result of Art 16 CFR. As regards the former point, the Directive was said to seek a fair balance between the interests of employees and transferee employers - in particular by ensuring that 'the transferee [was] in a position to make the adjustments and changes necessary to carry on its operations'. ${ }^{65}$

The provisions were furthermore to be read in the light of Article 16 of the Charter: 66

That fundamental right covers, inter alia, freedom of contract $[\ldots]$ it is apparent that, by reason of the freedom to conduct a business, the transferee must be able to assert its interests effectively in a contractual process to which it is party and to negotiate the aspects determining changes in the working conditions of its employees with a view to its future economic activity.' [As the transferee would be unable to participate in public sector bargaining, its] contractual freedom is seriously reduced to the point that such a limitation is liable to adversely affect the very essence of its freedom to conduct a business. ${ }^{9} 7$

As I have argued previously, the first strand of the Court's reasoning is problematic in and of itself: the Acquired Rights Directive stands out amongst EU employment legislation precisely because it does not require any balance of interests to be taken into account. ${ }^{68}$ For present purposes, however, the second strand, which pits Article 16

\footnotetext{
64 Alemo-Herron And Others v Parkwood Leisure Ltd, EU:C:2013:521, paragraph 20.

65 Alemo-Herron And Others v Parkwood Leisure Ltd, EU:C:2013:521, paragraph 25.

${ }^{66}$ Alemo-Herron And Others v Parkwood Leisure Ltd, EU:C:2013:521, paragraph 31.

${ }^{67}$ Alemo-Herron And Others v Parkwood Leisure Ltd, EU:C:2013:521, paragraphs 32-33, 35.

${ }^{68} \mathrm{~J}$ Prassl, 'Freedom of Contract as a General Principle of EU Law?' (n 9) 439-440.
} 
CFR against a worker-protective interpretation of the Acquired Rights Directive, will be of particular interest. ${ }^{69}$

Present space limitations prohibit a repeated in-depth engagement with the Court's decision in Alemo-Herron; suffice it to say that Alemo-Herron constitutes a significant departure from established case law. Fundamental rights are a legitimate review standard in EU law; ${ }^{70}$ the Court's peculiar interpretation of Article 16 CFR to justify the abrogation of employees' rights, on the other hand, is not. Furthermore, whilst the Acquired Rights Directive can undoubtedly be characterised as an 'intervention' abrogating freedom of contract, the provisions of Article 3 fall squarely within the definition of permissible restrictions on Charter rights as envisaged by Article 52(1) GFR.

It is therefore surprising that the Third Chamber felt able to conclude that because the post-transfer employer, Parkwood Ltd, could not be represented directly on the public sector bargaining body, its 'contractual freedom [was] seriously reduced to the point that such a limitation is liable to adversely affect the very essence of its freedom to conduct a business'. ${ }^{71}$ This stands in stark contrast with the test seen in Sky Österreich, above, that the 'core content' of Article 16 was unaffected as long as the relevant Directive had 'not prevent[ed] a business activity from being carried out as such'. 72

Indeed, when applying this test more broadly, it quickly becomes apparent that neither of the two core elements of the Acquired Rights Directive could be said to infringe Article 16 CFR: the duty to inform and consult affected employees set out in Article 7 CFR (Chapter III) will be of little harm to the employer's business freedom, as discussed further in the context of the Collective Redundancy Directive in subsection C, below. Even the automatic transfer of existing contractual obligations is unlikely to be a problem under Article 16 GFR, properly applied. First, because the

\footnotetext{
${ }^{69}$ For further criticism, see R Zahn, 'The Court of Justice of the European Union and Transfers of Undertakings: Implications for Collective Labour Rights' (2015) 6 ELLJ 72.

70 Stauder v Stadt Ulm, C-29/69, EU:C:1969:57, paragraph 7.

${ }^{71}$ Alemo-Herron And Others v Parkwood Leisure Ltd, EU:C:2013:521, paragraph 35.

72 Sky Österreich GmbH v Österreichischer Rundfunk, EU:C:2013:28, paragraph 49.
} 
design and subsequent operation of the Directive make it relatively easy for employers to structure transactions so as to avoid their falling within the scope of the Directive. ${ }^{73}$

Even where the sale or transfer of a business does fall within the definition of a relevant transfer of an undertaking, second, the acquirer's freedom of business is hardly affected. Whilst the Third Chamber in Alemo-Herron had been concerned that the established understanding of the ARD would deny transferees necessary 'room for manoeuvre', ${ }^{74}$ arguments along those lines are, with respect, difficult to sustain in the light of the Daddy's Dance Hall line of cases: the operation of the ARD does not mean that a transfer freezes employment conditions in all eternity, ${ }^{75}$ as 'there is nothing to prevent [the parties] from renegotiating the clause in the contract that refers to the collective agreement. ${ }^{76}$ On the other hand, as the Court of Justice had explicitly recognised in its previous decision in the case of Werhof $v$ Freeway Traffic Systems, the 'unconditional application' of freedom of contract to transfers of undertakings

could result in erosion of the rights which the employee has under his contract of employment and the collective agreement to which the employer transferring the undertaking was party, but not the transferee. That is why the Community legislature sought to ensure that, on transfer of an undertaking, employees enjoy special protection designed to prevent the erosion which could result from the application of that principle. ${ }^{77}$

\section{B The Collective Redundancies Directive}

The regulation of Collective Redundancies in the European Union, enshrined today in Council Directive 59 of 1998 on the approximation of the laws of the Member States relating to collective redundancies ${ }^{78}$ goes back to the days of the first Social

\footnotetext{
${ }^{73} \mathrm{C}$ Barnard, EU Employment Law (4 ${ }^{\text {th }}$ ed, OUP 2012) $581 \mathrm{ff.}$

${ }^{74}$ Alemo-Herron And Others v Parkwood Leisure Ltd, EU:C:2013:521, paragraph 28.

75 Foreningen af Arbejdsledere I Danmark v Daddy's Dance Hall, G-324/86, EU:C:1988:72.

${ }^{76}$ Opinion of Advocate General Cruz Villalón in Alemo-Herron, C-426/11, EU:C:2013:82, point 36.

77 Werhofv Freeway Traffic Systems GmbH \& Co KG, C-499/04, EU:C:2006:168, paragraph [24].

${ }^{78}$ Council Directive 59 of 1998 on the approximation of the laws of the Member States relating to collective redundancies OJ [1998] L 225/16 ('Collective Redundancies Directive').
} 
Action Programme (1974-76). ${ }^{79}$ As the preambles explain, the Union's collective redundancy apparatus is designed to protect workers in balance with company's rights, ${ }^{80}$ and to ensure a level playing field of protective standards across the EU. ${ }^{81}$ At the same time, however, none of the Directive's provisions are aimed at restricting the freedom of undertakings to organise their activities, nor intended to lay down rules relating to the internal organisation of undertakings or the management of their personnel, seeking instead to protect workers through strong procedural measures.

As the Court of Justice noted in Nielsen, ${ }^{82}$ the 'directive does not affect the employer's freedom to effect or refrain from effecting collective dismissals. Its sole object is to provide for consultation with the trade unions and for notification of the competent public authority prior to such dismissals. ${ }^{93}$ This was made even more explicit in Rockfon, ${ }^{84}$ with the Court confirming 'the freedom of undertakings to organize their activities and arrange their personnel departments in the way which they think best suits their need's. ${ }^{85}$ In Fujitsu Siemens, ${ }^{86}$ it similarly emphasised the fact that 'how the management of a group of undertakings is organised is an internal matter'. ${ }^{87}$

Focussing on the Directive's procedural regulation of collective redundancies, one might nonetheless imagine three potential grounds of challenge on the basis of the Charter's freedom to conduct a business: first, that its provisions interfere with the employer's decision-making process even if they do not stipulate a particular outcome; second, that the notification provisions give undue interference powers to public authorities; and third, that the consultation duty could be an undue interference with

\footnotetext{
${ }^{79}$ See Council Resolution of 21 January 1974 concerning a social action programme, OJ [1974] 013/1.

80 Collective Redundancies Directive (n 78) preamble 2.

${ }^{81}$ Collective Redundancies Directive (n 78) preamble 3.

${ }^{82}$ Dansk Metalarbejderforbund v H Nielsen E Son, C-284/83, EU:C:1985:61.

${ }^{83}$ Dansk Metalarbejderforbund v H Nielsen E Søn, EU:C:1985:61, paragraph 10.

${ }^{84}$ Rockfon A/S v Specialarbejderforbundet i Danmark, C-449/93, EU:C:1995:420.

${ }^{85}$ Rockfon A/S v Specialarbejderforbundet i Danmark, EU:C:1995:420, paragraph 21.

${ }^{86}$ Akavan Erityisalojen Keskusliitto AEK ry and Others v Fujitsu Siemens Computers Oy, C-44/08, EU:C:2009:533, paragraph 59.

${ }^{87}$ Akavan Erityisalojen Keskusliitto AEK ry and Others v Fujitsu Siemens Computers Oy, EU:C:2009:533, paragraph 59 .
} 
the employer's commercial secrets. When tested against Article 16 CFR, however, none of these grounds are likely to succeed.

The definitional provision found in Article 1(1)(a) of the Directive stipulates that "collective redundancies" means dismissals effected by an employer for one or more reasons not related to the individual workers concerned'. For a redundancy measure to be collective, and thus within the Directive's scope, Member States are offered a choice between different time and scale pairings, ranging from enterprisesize dependent numbers over a period of 30 days to a fixed number of at least 20 workers over 90 days. ${ }^{88}$ Once a potential measure falls within the Directive's scope, the employer's first duty is to inform and consult with workers, as set out in Article $2 .{ }^{89}$ This process is to begin when the employer is contemplating the redundancies, viz 'prior to any decision [having been taken] by the employer'. ${ }^{90}$

Could this constitute an interference with an employer's decision-making, and thus potentially the very essence of the freedom to conduct a business? The answer to this question depends to a large part on when the consultative obligation is triggered: the earlier an employer has to engage with workers potentially affected the proposed redundancies, the likelier Article 16 CFR will be engaged. In its initial jurisprudence, the Court of Justice had emphasised an early duty to consult, as it is impossible to comply with the Directive and avoid or reduce the number of terminations if consultation of workers' representatives came subsequent to the redundancy decision. ${ }^{91}$ In the (difficult) subsequent case of Fujitsu Siemens, ${ }^{92}$ however, the Court was less clear on this matter, at some point even appearing to suggest that the obligations are only triggered 'once a strategic or commercial decision ... has been taken. ${ }^{93} \mathrm{In}$ any instance, it is important always to remember that the Collective redundancy regime's emphasis is on the employer's procedural choices, and can therefore not

\footnotetext{
${ }^{88}$ Collective Redundancies Directive (n 78), Art 1(1).

89 This has drawn significant amounts of litigation. For full overview, see Barnard, EU Employment Law (n 73) 635-40.

90 Junk v Kühnel, G-188/03, EU:C:2005:59, paragraph 37.

91 Junk v Kühnel, EU:C:2005:59, paragraph 38.

92 See further J Prassl, The Concept of the Employer (OUP 2015) $96 \mathrm{ff}$.

${ }^{93}$ Akavan Erityisalojen Keskusliitto AEK ry and Others v Fujitsu Siemens Computers Oy, EU:C:2009:533, paragraph 48 .
} 
'interfere with the employer's decision to restructure' ${ }^{94}$ - a set of requirements unlikely even to engage Article 16 GFR.

Once the consultative duties apply, worker representatives and the employer are to engage in the process of information and consultation 'with a view to reaching agreement'. The 'consultations shall, at least, cover ways and means of avoiding collective redundancies or reducing the number of workers affected, and of mitigating the consequences by recourse to accompanying social measures aimed, inter alia, at aid for redeploying or retraining workers made redundant'. ${ }^{95}$ While the textual basis thus appears to be a rather strong version of collective bargaining, the Court has once more made it clear that the obligations are primarily procedural. ${ }^{96}$

The employer's provision of information to worker representatives covers a broad range of items:97 (i) the reasons for the projected redundancies; (ii) the number of categories of workers to be made redundant; (iii) the number and categories of workers normally employed; (iv) the period over which the projected redundancies are to be effected; (v) the criteria proposed for the selection of the workers to be made redundant in so far as national legislation and/or practice confers the power therefor upon the employer; [and] (vi) the method for calculating any redundancy payments other than those arising out of national legislation and/or practice; as well as 'all relevant information' more broadly.

This extensive list of disclosure requirements, likely also to include commercially important details, ${ }^{98}$ could be said to engage Article 16 CFR insofar as it is a prima facie violation of the protection of business secrets, recognized as a general principle of European Union law, ${ }^{99}$ and linked to the freedom to conduct a business by the Court of Justice in Interseroh. ${ }^{100}$ Given the limited scope of the obligation and its clear connection to the Directive's aims, however, the consultation requirements are

\footnotetext{
${ }^{94}$ Barnard, EU Employment Law (n 73) 629.

${ }^{95}$ Collective Redundancies Directive (n 78), Art 2(2).

${ }^{96}$ See eg Junk v Kühnel, EU:C:2005:59, paragraph 44.

${ }_{97}$ Collective Redundancies Directive (n 78), Art 2(3)(b).

${ }_{98}$ UK Coalmining Ltd v NUM EAT/0397/06; see further Barnard, EU Employment Law (n 73) 638 and the cases discussed there.

${ }^{99}$ Varec SA v Belgium, C 450/06, EU:C:2008:91, paragraph 49.

${ }^{100}$ Interseroh Scap Metal Trading, C-1/11, EU:C:2012:194, paragraph 43.
} 
likely to constitute a proportionate restriction on the employer's freedom to conduct a business - especially because the Court has only recently re-emphasised that in interpreting the information provisions, 'flexibility is essential', ${ }^{101}$ for example as regards the timing when information is to be provided.

The employer's second key duty under the Directive is to provide information of the impeding collective redundancy to a 'competent public authority'. ${ }^{102}$ The content of the notification once more appears to be wide-ranging: the second paragraph of Article 3(1) stipulates that such notices shall contain 'all relevant information concerning the projected collective redundancies and the consultations with workers' representatives provided for in Article 2, and particularly the reasons for the redundancies, the number of workers to be made redundant, the number of workers normally employed and the period over which the redundancies are to be effected.' A copy of the notification is to be provided to the workers' representatives, who may engage in direct dialogue with the relevant public authority. ${ }^{103}$

It is likely that the conclusions as regards these information provisions will be similar to those just discussed in relation to worker representatives - indeed, the results of a proportionality enquiry are if anything even more straightforward to predict, as the information provided will be necessary for the authority in turn to comply with the various obligations placed on it by Union and domestic law.

A slightly more difficult question might arise, however, in Member States which have granted extended powers (up to and including a ban on redundancies) to the relevant authorities, such as is the case for example in the Netherlands. ${ }^{104}$ The original design scheme of the Directive had included just such 'powers on the part of public authorities to postpone or prohibit dismissals in certain circumstances'. Following UK resistance, however, it was made 'optional to Member States whether

\footnotetext{
${ }^{101}$ Akavan Erityisalojen Keskuslïtto AEK ry and Others v Fujitsu Siemens Computers Oy, EU:C:2009:533, paragraph 53.

102 Collective Redundancies Directive (n 78), Art 3.

103 Collective Redundancies Directive (n 78), Art 3(2).

104 Barnard, EU Employment Law (n 73) 640-41.
} 
or not to grant veto powers over collective dismissals to their Departments of Employment.'105

Today, that debate is reflected in the provision that 'Member States may grant the competent public authority wider powers of extension' of the time period during which the projected collective redundancies may not take effect. ${ }^{106}$ Even given this rather more direct interference with employers' decision-making powers (viz, by limiting their power to effect collective redundancies, at least for a certain period of time), however, it is unlikely that a challenge under Article 16 CFR would succeed. Even though the article might be engaged, any interference could be justified: first, by reference to Article 5 of the Directive, which confirms 'the right of Member States to apply or to introduce laws, regulations or administrative provisions which are more favourable to workers'. Second, because such bans can be linked clearly to the purpose of Article 4(3), granting the competent authorities the necessary additional time 'where the problems raised by the projected collective redundancies are not likely to be solved within the initial period.' The provisions are, finally, highly unlikely to be found to be disproportionate in the narrow sense of that test of affecting 'the core content of the freedom to conduct a business', as the public authority's involvement would 'not prevent a business activity from being carried out as such.' ${ }^{107}$

In conclusion, then, it is unlikely that Article 16 CFR poses a serious threat to the Collective Redundancies Directive: the measure's interference with employers' freedom is minimal, and can in any event be justified. This conclusion is unsurprising given that, as Anne Davies has noted, the Directive 'fits with [the EU's "flexicurity" agenda] in the sense that it does not provide workers with any strong form of job security' by focussing 'on their employability in the EU market generally, rather than on attaching themselves to a particular job with a particular firm.' 108

\section{G The Working Time Directive}

\footnotetext{
${ }^{105}$ M Freedland, 'Employment Protection: Redundancy Procedures and the EEC' (1976) 5 ILJ 24, 27.

106 Collective Redundancies Directive (n 78), Art 4(3).

107 Sky Österreich GmbH v Österreichischer Rundfunk, EU:C:2013:28, paragraph 49.

108 ACL Davies, EU Labour Law (Elgar 2012) 220.
} 
Working time and annual leave have been regulated at Union level for over twenty years, ${ }^{109}$ with the current regime laid down in the Working Time Directive 88 of 2003. ${ }^{110}$ Situated 'in the grey area between traditional health and safety measures and the rights of employed persons', ${ }^{111}$ the measure soon became the subject of highprofile disputes ${ }^{112}$ which continue to this day. ${ }^{113}$ The Directive provides an interesting third example for scrutiny under Article 16 GFR; not least because it has been criticised both for being too rigid in its worker-protective goals, and could therefore be characterised as a potentially excessive burden on workers, and as being too flexible, thus failing to provide workers with any meaningful rights. ${ }^{114}$ As Norbert Reich has recently suggested, the Working Time Directive is furthermore one of the leading examples of the emerging general principle of the protection of the weaker party, which could be seen as sitting at odds with the business freedoms now enshrined in the Charter: the 'worker is seen as the typically weaker party in employment contracts who needs to be protected against a unilateral use of the contractual freedom of the employer'. ${ }^{115}$

It is, finally, apposite to conclude with Working Time Directive given the historical precedent in this area of employment regulation. The law struck down as 'an unreasonable, unnecessary and arbitrary interference with the right and liberty of the individual to contract in relation to labo[u]r ${ }^{\prime 16}$ by the United States Supreme Court in its infamous 1905 decision of Lochner v New York was none other than the Bakeshop Act of 1895, designed amongst other things to limit weekly working hours in bakeries. Whilst Lochner is in one sense easily dismissible as an historic 'high point in the judicial espousal of laissez faire economics', ${ }^{117}$ it serves at the same time as a clear

\footnotetext{
${ }^{109}$ Council Directive 93/104/EG of 23 November 1993 concerning certain aspects of the organization of working time [1993] OJ L307/18.

110 Directive 2003/88/EG of the European Parliament and of the Council of 4 November 2003

concerning certain aspects of the organisation of working time [2003] OJ L299/9 ('Working Time

Directive').

${ }^{111}$ Barnard, EU Employment Law (n 73) 533.

112 UK v Council, G-84/94, EU:C:1996:431.

113 Especially as regards the opt-out: Barnard, EU Employment Law (n 73) 555-551

114 See Davies, EU Labour Law (n 108) 203-4 and the sources cited there.

115 Reich, General Principles of EU Civil Law (n 61) 41.

${ }^{116}$ Lochner v New York 198 US 45, 45. Though cf notably Justice Holmes' dissent, ibid 74ff.

117 S Sedley, 'Public Law and Contractual Employment' (1994) 23 ILJ 201, 207.
} 
reminder of the 'deeper tension between the interests of working people and the language of rights', ${ }^{118}$ brought to the fore once more - albeit on this occasion within the scope of Union law - by the operation of Article 16 CFR.

The Working Time Directive is designed around a series of time limits and rest entitlements, ${ }^{119}$ including a weekly day off in the form of 'a minimum uninterrupted rest period of 24 hours plus the 11 hours' daily rest referred to in Article 3', ${ }^{120}$ daily rest of at least 11 uninterrupted hours per 24 hour period, ${ }^{121}$ and breaks when a day's work exceeds 6 hours. ${ }^{122}$ Perhaps most controversially, 'the average working time for each seven-day period, including overtime, [must not] not exceed 48 hours'. ${ }^{123}$ Provisions are also made to regulate night work, ${ }^{124}$ and a right to at least four weeks' annual leave with pay. ${ }^{125}$

Many of these entitlements and limits, however, are less restrictive on employers' freedom to organise their operations than might at first appear. Article 17 of the Directive, for example, provides for several explicit derogations, such as 'managing executives or other autonomous decision-taking powers'. ${ }^{126}$ Article 22(1) makes provisions for a system under which Member States can permit employees to waive the 48-hour limit to weekly working time, and Chapter 5 of the Directive contains a myriad of further derogations beyond the scope of the present discussion, including notably through collective bargaining. ${ }^{127}$ At the same time, Member States remain free 'to apply or introduce laws, regulations or administrative provisions more favourable to the protection of the safety and health of workers'. ${ }^{128}$

\footnotetext{
118 C Estlund, 'An American perspective on fundamental labour rights' in B Hepple (ed), Social and Labour Rights in a Global Context: International and Comparative Perspectives (CUP 2002) 210.

119 For criticism of that distinction, see Barnard, EU Employment Law (n 73) 537-8,

120 Working Time Directive (n 110) 5.

121 Working Time Directive (n 110) Art 3.

122 Working Time Directive (n 110) Art 4.

${ }^{123}$ Working Time Directive (n 110) Art 6.

${ }^{124}$ Working Time Directive (n 110) Arts 8 -11.

125 Working Time Directive (n 110) Art 7. Financial payments in lieu are only allowed when the employment is terminated.

126 Working Time Directive (n 110) Art 17(1)(a).

127 Though cf notably Pfeiffer v Deutsches Rotes Kreuz, C-397/01, EU:C:2004:584.

128 Working Time Directive (n 110) Arts 15, 23.
} 
As Barnard has noted, 'many businesses [view] the Working Time Directive as a significant constraint on their ability to introduce flexible working arrangements'. ${ }^{129}$ This is despite a wide-spread use of opt-outs, even in situations where 'they do not actually need it, but it provides them with a security blanket in case of breach.' ${ }^{130}$ Potential arguments for an Article 16 GFR challenge are therefore not difficult to make out. The provisions of the Directive could be said, first, to violate employers' freedom to conduct business given their financial and organisational implications: empirical studies point to at least some employers' concerns that 'the costs of running their business would increase significantly as they would have to recruit more labour to do the work.' ${ }^{131}$ In Kiel v Fäger, for example, the Court held that doctors present at a hospital during on-call shifts would fall within the Directive's definition of working time. At face value, this could lead to significant additional cost for hospital providers, both in terms of needing to provide their staff with rest breaks, and the cost of hiring additional, highly qualified, medical personnel.

A second potential concern arises from the fact that certain elements of the Working Time regime, in particular those relating to paid annual leave, cannot be varied contractually, even where this might be agreed upon as a positive arrangement by the parties overall. ${ }^{132}$ This approach is not only 'unlikely ... [to] serve workers' interests in the longer term', ${ }^{133}$ but could also be seen as a limitation on the parties' freedom to contract for alternative arrangements, such as 'rolled-up pay', where workers receive holiday pay in small increments added to their regular wage.

That said, it is unlikely that these interferences would amount to a sufficiently serious violation of Article 16 CFR. Applying the test developed in Sky, above, neither time limits nor the duty to provide for annual paid leave affect the core content of the freedom to conduct a business, as they do not prevent a business activity from being carried out as such. The present, low degree of interference is furthermore clearly justifiable. In that regard, it is important first to remember that economic arguments

\footnotetext{
129 Barnard, EU Employment Law (n 73) 558.

130 Barnard, EU Employment Law (n 73) 558.

${ }^{131}$ C Barnard, S Deakin and R Hobbs, 'Opting out of the 48 Hour Week: Employer Necessity or Individual Choice?' (2003) 32 ILJ 223, 237.

132 Robinson-Steele v RD Retail Services Ltd, C-131/04, EU:C:2006:177.

${ }_{133}$ A Bogg, The right to paid annual leave in the Court of Justice: the eclipse of functionalism' (2006)

31 ELRev 892, 905.
} 
in and of themselves will not hold much sway - if such economic harm can be made out in the first place. The already-cited empirical study by Barnard, Deakin, and Hobbs found that working time limits helped employers to avoid 'inefficient utilisation of labour' and thus improved efficiency, for example by saving overtime payments or avoiding increases in workforce sickness following long shifts. ${ }^{134}$ In any case, in its fäger judgment the Court dismissed similar economic arguments, noting that the Directive's broad 'interpretation cannot be called in question by the objections based on economic and organisational consequences which, according to the five Member States which submitted observations ... would result from' its judgment. ${ }^{135}$

The argument that the measures are therefore a proportionate interference with the freedom to conduct a business will be strengthened further by their clear link to the right to fair and just working conditions in Article $31 \mathrm{CFR},{ }^{136}$ including the protection of health and safety - a rationale been accepted by the Court early on. ${ }^{137}$ Finally, and notwithstanding the stipulation in Article 153(2)(b) TFEU that any measures enacted on its basis 'shall avoid imposing administrative, financial and legal constraints in a way which would hold back the creation and development of small and medium-sized undertakings, ${ }^{138}$ the Directive itself explicit provides that health and safety concerns should trump arguments based on the additional financial burden: 'the improvement of workers' safety, hygiene and health at work is an objective which should not be subordinated to purely economic considerations. '139

In BECTU, the United Kingdom government had suggested that certain domestic exemptions for short engagements were necessary to avoid the imposition of

\footnotetext{
134 Barnard, Deakin and Hobbs, 'Opting out of the 48 Hour Week' (n 131) 238

135 Landeshauptstadt Kiel v Norbert Faeger, C-151/02, EU:G:2003:437, paragraph 66.

136 As Barnard, EU Employment Law (n 73) 551 has suggested, 'following Test-Achats (Case C-236/09

[2011] ECR I-nyr), the absence of a sunset clause on the opt-out might be challenged as contrary to Article 31(2) of the Charter'.

137 Not least because of the challenge in $U K v$ Council, EU:C:1996:431. See further Bercusson, European Labour Law (n 2) 59-61.

138 Mirroring the language in its predecessor provision, Art $118 \mathrm{a}$ TEC.

139 Working Time Directive (n 110), Recital 5. As cited by the Court in $R v$ Secretatory of State for Trade and Industry, ex parte Broadcasting, Entertainment, Cinematographic and Theatre Union (BECTU), C-173/99, EU:C:2001:356, paragraph 59.
} 
excessive financial burdens on small and medium-sized businesses. ${ }^{140}$ In rejecting this submission, the Court found that this argument had clearly been based on the very considerations proscribed by Recital 5. ${ }^{141}$ It furthermore pointed out that as the Directive's Treaty basis had already stipulated concern for small and medium-sized enterprises, 'the directive has already taken account of the effects which the organisation of working time for which it provides may have on small and mediumsized undertakings'. ${ }^{142}$

In summary, then, it is difficult to see how the provisions of the Working Time Directive could be held to violate Article 16 CFR, given that the Court of Justice's case law in this field 'shows - despite strong protests by Member State governments and employers' associations - a remarkably protective spirit'. ${ }^{143}$ As discussion in this final sub-section has shown, even where employers' freedom to conduct their business might prima facie be engaged, the measure's pursuit of employee rights would easily be found to be proportionate.

\section{Conclusion}

It had always been envisaged that the development of the Union's internal market would lead to a significant increase in business freedoms, whether through daily trading activity in growing markets, or the development of new enterprise structures. ${ }^{144}$ At the same time, however, the Union legislator soon realised that many of these developments were likely to bring with them uncertainty, or downright negative changes, for workers. This realisation, and the advent of economic crises across the (then) Community, ${ }^{145}$ provided an early impetus for the enactment of

\footnotetext{
${ }^{140} R v$ Secretatory of State for Trade and Industry, ex parte Broadcasting, Entertainment, Cinematographic and Theatre Union (BECTU), EU:C:2001:356, paragraph 57.

${ }^{141} R v$ Secretatory of State for Trade and Industry, ex parte Broadcasting, Entertainment, Cinematographic and Theatre Union (BECTU), EU:C:2001:356, paragraph 59.

${ }^{142} R v$ Secretatory of State for Trade and Industry, ex parte Broadcasting, Entertainment, Cinematographic and Theatre Union (BECTU), EU:C:2001:356, paragraph 60.

143 Reich, General Principles of EU Civil Law (n 61) 41.

144 Acquired Rights Directive (n 7), preamble (2).

${ }^{145}$ Davies, EU Labour Law (n 108) 217. When financial crises once more began to rear their head in recent years, however, the rhetoric had changed, with deregulation to achieve labour market flexibility
} 
employee-protective measures, ${ }^{146}$ including the three Directives scrutinised in this article.

Following the Court of Justice's decision in Alemo-Herron, it appeared that the freedom to conduct a business enshrined in Article 16 of the Charter of Fundamental Rights might pose a serious challenge to employee-protective measures in the Member States and at the Union level by forming the basis for a restrictive interpretation of, or even downright challenges to, the very core of employment protective measures. As discussion in the preceding sections has shown, however, given the current understanding and application of the freedom to conduct a business, it is likely that Alemo-Herron will instead be consigned to the bottom of Weatherill's icy lake.

Furthermore, whilst the focus of the present article has been on Article 16 CFR's manifestation as a subjective right, it is important not to forget the fact that its 'dual character' also includes an important constitutional dimension. ${ }^{147}$ In this connection, Article 16 CFR poses equally difficult questions in the broader debate surrounding the future of the European Union's economic constitution, ${ }^{148}$ and the extent to which market freedoms ought to be balanced against social concerns in general, ${ }^{149}$ as well as the extent to which individual and collective labour rights will be able to limit broader economic freedoms. On the one hand, 'one of the evident trends in European Union employment law has been a gradual shift towards the constitutionalization of key workers' rights', ${ }^{150}$ not least because of their recognition in

\footnotetext{
as a new guiding star: J Prassl, 'Contingent Crises, Permanent Reforms: Rationalising Labour Market Reforms in the European Union' (2014) 5 ELLJ 211.

146 See eg Commission Report on Council Directive 2001/23/EC of 12 March 2001 on the approximation of the laws of the Member States relating to the safeguarding of employees' rights in the event of transfers of undertakings, businesses or parts of undertakings or businesses (Brussels, 18 June 2007) $\mathrm{COM}(2007) 334$ final.

${ }^{147}$ A detailed discussion about the extent to which the constitutionalisation of commercial interests as fundamental rights could pose a threat to the Union's established economic constitution lies beyond the scope of the present discussion. See HW Micklitz, 'Introduction' in HW Micklitz (ed), Constitutionalization of European Private Law (OUP 2014).

${ }^{148} \mathrm{H}$ Collins, 'The European Economic Constitution and the Constitutional Dimension of Private Law’ (2009) 2 ERCL 1.

${ }^{149}$ M Poiares Maduro, 'Striking the Elusive Balane Between Economic Freedom and Social Rights in the EU' in P Alston (ed) The EU and Human Rights (OUP 1999) 449.

${ }^{150} \mathrm{M}$ Bell, 'Constitutionalization and EU Employment Law' in HW Micklitz (ed), Constitutionalization of European Private Law (OUP 2014) 137.
} 
the Charter. On the other, commentators such as Carsten Herresthal who appear (curiously) concerned that 'the structure of the balance of interests will usually result in an excess of consumer protection, anti-discrimination and other EU regulation' have argued that whilst historically 'the principles of a market economy, such as freedom of contract, may lack sufficient weight in a conflict with welfare state rules', ${ }^{151}$ Article 16 of the Charter may provide the basis for a renewed emphasis on Union law's economic concerns.

In conclusion, then, it is imperative that labour lawyers across the European Union continue to engage with Article 16 GFR - not only because its application in casu will continue to be difficult to predict, ${ }^{152}$ but also given the broader constitutional questions involved. As Tonia Novitz and Phil Syrpis have argued, 'it is not unrealistic ... to expect labour lawyers to feed into the debate about the policy priorities within the internal market, and about the institutional structures to be utilized in the realisation of those priorities. ... [They need] to make their arguments in a way that, while it may of course be highly critical of, is nevertheless sensitive to, the logic of those systems.' ${ }^{153}$ It is hoped that the present article has contributed to that process, by scrutinising Article 16 of the Charter of Fundamental Rights, and demonstrating the range of counterarguments, procedural and substantive, which balance the Union's labour law acquis against employers' freedom to conduct a business - and which 'may yet become yet another vital front on which the contested effort to define Europe's emerging and ever-changing Economic Constitution will be concentrated'. ${ }^{154}$

\footnotetext{
${ }^{151}$ C Herresthal, 'Constitutionalisation of Freedom of Contract in European Union Law' in K Ziegler and P Huber (eds) Current Problems in the Protection of Human Rights (Hart 2013) 108; 115.

152 C Semmelmann, 'The European Union's Economic Constitution under the Lisbon Treaty: SoulSearching Among Lawyers Shifts the Focus to Procedure' (2010) 35 ELR 516, 541.

153 P Syrpis and T Novitz, 'The EU Internal Market and Domestic Labour Law' in A Bogg, C Costello, A Davies, and J Prassl (eds), The Autonomy of Labour Law (Hart 2015) 291, 292.

${ }^{154}$ Everson and Correia Gonçalves, 'Article 16’ (n 6) 449.
} 